\title{
Factors Affecting the Coronavirus Fear Levels of Nurses
}

\section{Hemşirelerin Koronavirüs Korku Düzeylerini Etkileyen Faktörler}

\author{
Mustafa Durmuş ${ }^{1}$ (iD) Oktay Ferdi Yıldız ${ }^{2}$ (D) Hasan Köse ${ }^{3}$ \\ ${ }^{1}$ Department of Gerontology Faculty of Health Sciences,Mus Alparslan University, Muş, TURKEY \\ ${ }^{2}$ Malazgirt Vocational School, Muş Alparslan University, Muş, TURKEY \\ ${ }^{3}$ Vocational School of Health Services, Bingöl University, Bingöl, TURKEY
}

Geliş tarihi/ Date of receipt: 10/12/2020 Kabul tarihi/ Date of acceptance: 07/07/2021

(c) Ordu University Faculty of Health Sciences, Department of Nursing, Turkey, Published online: 08/09/2021

\begin{abstract}
Objective: This study was conducted to examine the coronavirus fear levels of nurses and the factors affecting them during the COVID19 outbreak.

Method: Research was carried out with nurses working in two public hospitals located in Turkey's Eastern Anatolia region between 1-30 June 2020. In this study, all nurses were tried to be reached and a sample from the population was not chosen. The research sample was calculated as 420 nurses at 95\% confidence interval, and it was completed with 421 nurses. "Personal Information Form" and "Coronavirus Phobia Scale (C19P-S)" were used in data collection. After obtaining the approval of the ethics committee for the research, data were collected online voluntarily basis. Frequency, percentage calculation, independent groups t-test and one-way ANOVA test were used in the evaluation of the data.

Findings: The total coronavirus fear levels of the nurses $(53.09 \pm 13.62)$ and social fear levels $(14.36 \pm 4.13)$ were found to be moderate. Psychological fear levels $(19.14 \pm 4.91)$ were determined to be above average. Somatic $(10.56 \pm 3.84)$ and economic $(9.01 \pm 2.85)$ coronavirus fear levels were found to be below average. A statistically significant difference was found between the nurses' gender, educational status, income levels, their employment in risky units, their belief that the coronavirus would end soon, and their coronavirus fear levels $(\mathrm{p}<0.05)$.

Conclusion: It was found in this study that women, those with low income, and nurses working in COVID-19 units were found to have higher coronavirus fears. It is recommended that the working conditions of the nurses would be improved and the nurses would be involved in in-service trainings regarding how to cope with outbreaks and crises.
\end{abstract}

Keywords: COVID-19, coronavirus, fear, nurse

ÖZ

Amaç: Bu çalışma, COVID-19 salgını süresi içinde hemşirelerin koronavirüs korku düzeylerini ve bu düzeyi etkileyen faktörlerin incelenmesi amacıyla yapılmıştır.

Gereç ve Yöntem: Araştırma, 1-30 Haziran 2020 tarihleri arasında Türkiye'nin Doğu Anadolu Bölgesinde yer alan iki devlet hastanesinde çalışan hemşireler ile yürütülmüştür. Bu çalışmada evrenden örneklem seçimine gidilmeyerek tüm hemşirelere ulaşılmaya çalışılmıştır. Araştırma örneklemini \%95 güven aralığında 420 hemşire olarak hesaplanmış, 421 hemşire ile tamamlanmıştır. Veriler Google Formlar ile toplanmış, hemşireler ile link paylaşılmıştır. hazırlanarak hemşirelere gönderilen bağlantı adresi ile toplanmıştır. Veri toplamada "Sosyo demografik Bilgi Formu " ve "Koronavirüs Korku Ölçegi (C19P-S)"' kullanılmıştır. Araştırma için etik kurul onayı alındıktan sonra veriler toplanmıştır. Verilerin değerlendirmesinde frekans, yüzdelik hesaplama, bağımsız gruplarda t testi ve one way Anova testi kullanılmıştır.

Bulgular: Hemşirelerin toplam koronavirüs korku düzeyleri (53.09 \pm 13.62$)$ ile sosyal korku düzeyleri (14.36 \pm 4.13$)$ orta seviyededir. Psikolojik korku düzeylerinin (19.14 \pm 4.91$)$ ortalamanın üstünde olduğu belirlenmiştir. Somatik (10.56 \pm 3.84$)$ ve ekonomik (9.01 \pm 2.85$)$ koronavirüs korku düzeylerinin ortalamanın altında olduğu saptanmıştır. Hemşirelerin cinsiyet, eğitim durumları, gelir durumları, riskli birimlerde görev alma durumları, koronavirüsün kısa sürede biteceğine inançları ile koronavirüs korku düzeyleri arasında istatistiksel olarak anlamlı bir fark bulunmuştur $(\mathrm{p}<0.05)$.

Sonuç: Sonuç olarak bu çalışmada kadınların, gelir düzeyi düşük olanların ve COVID-19 birimlerinde çalışan hemşirelerin koronavirüs korkularının daha yüksek olduğu tespit edildi. Hemşirelerin çalışma koşullarının iyileştirilmesi ve hemşirelere yönelik salgın ve krizlere yönelik baş etme eğitimlerine daha fazla yer verilmesi önerilmektedir.

Anahtar kelimeler: Covid-19, koronavirüs, korku, hemşire

ORCID IDs of the authors: MD: 0000-0002-7559-4187; OFY: 0000-0002-9760-4892; HK: 0000-0002-1504-700X

Sorumlu yazar/Corresponding author: Mustafa Durmuş

Department of Gerontology Faculty of Health Sciences, Mus Alparslan University 49100, Muş, TURKEY

e-posta/e-mail: saremeryem01@gmail.com

Atıf/Citation: Durmuş M, Yıldız OF, Köse H. (2021). Factors Affecting the Coronavirus Fear Levels of Nurses. Ordu Üniversitesi Hemșirelik

Çalı̧̧maları Dergisi, 2021, 4(2), 189-196. DOI:10.38108/ouhcd.838675 


\section{Introduction}

Coronavirus (COVID-19), a new type of virus, first started in Wuhan, China in late December 2019 and continues all over the world with a continuous viral pneumonia epidemic (Guan et al., 2020; Paules et al., 2020). COVID-19 is a new and serious problem, and limited information is available about risk factors. COVID-19 poses a higher risk for individuals over 65 with chronic diseases such as hypertension, diabetes, obesity and immunosuppressive problems (Ueda et al., 2020).

COVID-19 is an acute and fatal disease, plus the average case fatality rate is $2 \%$ (Xu et al., 2020). COVID-19 causes severe respiratory diseases associated with mechanical ventilation and high mortality (Huang, 2020). The most common symptoms of COVID-19 are noted to be fever, chills, cough, weakness, and shortness of breath (Guan et al., 2020; Xu et al., 2020; Huang et al., 2020).

It is emphasized that fear is a characteristic nature of infectious diseases compared to other conditions. Fear is directly related to the transmission rate, environment, morbidity and mortality of the disease. This also leads to other psychosocial difficulties such as stigmatization, discrimination, and loss (Pappas et al., 2009).

The infection caused by COVID-19 and the high mortality rate and the thought of contacting people diagnosed with COVID-19 cause an increase in the levels of fear and anxiety of individuals (Lin,2020). The fear of COVID-19 causes an increase in physiological and psychological problems in individuals. It was stated that the COVID-19 outbreak can cause psychological disturbances such as post-traumatic stress disorder, acute stress disorder, depression, and suicidal behaviors. Also, the emergence and pandemic nature of COVID-19 is stated to increase the fear of stigmatization in individuals (Guan et al., 2020; Huang et al., 2020; Lin, 2020).

Nurses, who are at the forefront of this global critical care crisis and the unique health emergency, are the largest health professions that provide and continue to provide essential care (Pappas et al., 2009; Li et al., 2003). Nursing, which is based on a scientific and theoretical basis, is a health discipline that deals with the health of individuals, families and the society in general, and includes practical skills, has a vital importance for sick individuals in terms of the services it provides (Akça, 2010). The services provided by nurses are services that cannot be met by sick people or any member of the society (Öz, 2015). The physiological and mental state of nurses, who are healthcare practitioners and professionals, are also very important and affect both their social life and fulfilling the responsibilities imposed by the profession (Muşlu et al., 2012; Khamisa et al., 2013; Kızılırmak and Demir, 2016).

Therefore, more research is needed to clarify nurses' coping strategies and emotional response during a major infectious disease such as COVID19.

\section{Methods \\ Study Design}

This study was planned as a cross-sectional and descriptive design to examine the coronavirus fear levels of nurses and the factors affecting them during the COVID-19 outbreak.

\section{Setting and Sampling}

The research was carried out with nurses working in two public hospitals located in Turkey's Eastern Anatolia region between 1-30 June 2020. Nurses actively working in two public hospitals that are in Turkey's Eastern Anatolia region constituted the universe of the study. A sample was not chosen for the study, 640 actively working nurses during the specified dates were reached and 421 nurses who agreed to participate in the study constituted the sample of the study.

A total of 987 nurses work in the two state hospitals that were included in the study. The research sample was calculated as 420 nurses at a 95\% confidence interval and completed with 421 nurses (Cohen et al., 2013).

\section{Ethical Considerations}

Permission of conducting the study was granted by the Institutional Review Board (IRB) of the university with the date:29/05/2020 and number:10879717-050.01.04. After the researchers interviewed the nurses face-to-face and gave information about the study, they sent the link of the study to the nurses who agreed to participate in the study. Nurses were informed verbally about the study, taking into account social distance. Verbal consent to participate in the research was obtained from the individuals by giving information about the purpose of the research, the method, the time they would spare for the research, and by declaring that participating in the research would not do any harm and that the participation was completely voluntary. 


\section{Measurements}

\section{Personal Information Form}

This form was prepared by the researchers to determine the participants' characteristics, which included seven questions in total regarding their gender, age, marital status, educational status, economic status, and working status in coronavirus units (Baksi et al., 2020; Çankaya and Eriş, 2020; Durmuş et al., 2017; Korkmazer et al., 2020; Köse and Sis Çelik, 2020).

\section{The Coronavirus Phobia Scale (C19P-S)}

The Coronavirus Phobia Scale (C19P-S) is a 5grade Likert-type self-assessment scale developed to measure the phobia that can develop against the coronavirus. Scale items are evaluated between 1 "Strongly Disagree" and 5 "Strongly Agree". Items 1, 5, 9, 13, 17 and 20 measure Psychological SubDimension. Items 2, 6, 10, 14 and 18 measure Somatic Sub-Dimension. Items 3, 7, 11, 15 and 19 measure Social Sub-Dimension. Items 4, 8, 12 and 16 measure the Economic Sub-Dimension. Subdimension scores are obtained by the total score of the answers given to the items of that subdimension. The total C19P-S score is obtained by the sum of the sub-dimension scores and ranges from 20 to 100 points. Higher scores indicate severeness in sub-dimensions and overall coronaphobia (Arpac1 et al., 2020).

\section{Data Analysis}

The SPSS 24.0 software package was used to analyze the data collected in this study. Frequency, percentage calculation, t-test, and one-way ANOVA test were used in the analysis of the data. The conformity of the data to the normal distribution was assessed using the Kolmogorov-Smirnov Test; the test to be applied was selected based on the results of this test. The statistical significance level for all data was assumed to be $\mathrm{p}<0.05$.

\section{Results}

When the distribution of the introductory characteristics of the participating nurses was examined (Table 1), it was found that $36.1 \%$ were 30 years old and above, $60.3 \%$ were female, $69.8 \%$ were holding bachelor's degree, $61.8 \%$ were single, $50.4 \%$ of the individuals had equal income to their expenses, and $52 \%$ of them had work experience in the range of 0-4 years. Besides, $55.6 \%$ of the nurses lived with their families, $86.9 \%$ did not have any chronic diseases, $65.3 \%$ worked in coronavirus units, $81 \%$ had sufficient information about the coronavirus, $83.1 \%$ did not believe that the coronavirus would end in a short time. Also, it was determined that $61.8 \%$ believed that the coronavirus was produced in a laboratory environment, and $67.5 \%$ reported that no one was diagnosed with COVID-19 in their immediate surroundings.

The comparison of the mean scores of the nurses according to their descriptive characteristics is shown in Table 2.

It was determined that the mean scores of the CP19-S sub-dimension of the nurses were $19.14 \pm$ 4.91 in psychology, $10.56 \pm 3.84$ in somatic, 14.36 \pm 4.13 in social, $9.01 \pm 2.85$ in economics, and 53.09 \pm 13.62 in total in CP19-S (Table 2).

The comparison of the mean CP19-S score according to sociodemographic characteristics of the nurses was shown in Table 3.

When the average scores according to gender are compared, Coronavirus fear levels of female nurses were higher than male nurses, and while no statistically significant difference was found in the economic sub-dimension by gender ( $p>0.05)$, there was a significant difference between the subdimensions and averages of the total score $(p<0.05)$.

When the scale score averages of the nurses are compared according to their education level, there was a statistically significant difference between educational status and somatic and social subdimensions $(\mathrm{p}<0.05)$. Statistically significant difference was found between the sub-dimensions and averages of the total score ( $\mathrm{p}<0.05)$.

The fear levels of the nurses with higher income were lower than other income groups and a statistically significant difference was found between the sub-dimensions and averages of the total score $(\mathrm{p}<0.05)$.

Statistically significant difference was found between the nurses' employment status in the coronavirus units and the somatic sub-dimension $(\mathrm{p}<0.05)$, while no statistically significant difference was found between the sub-dimensions and averages of the total score $(p>0.05)$.

Statistically significant difference between the nurses' beliefs that the coronavirus will end in a short time and the somatic, psychological, and social sub-dimensions and averages of the total score ( $p$ $<0.05)$ was found.

No statistically significant difference was found between the nurses' introductory characteristics, such as age and marital status, and CP19-S subdimensions and averages of total scores ( $p>0.05$ ) (Table 3). 
Table 1. Introductory characteristics of nurses (n: 411)

\begin{tabular}{|c|c|c|c|}
\hline Characteristics & & $\mathbf{n}$ & $\%$ \\
\hline Age & $\begin{array}{l}18-24 \text { years } \\
25-29 \text { years } \\
30 \text { years and above }\end{array}$ & $\begin{array}{l}120 \\
149 \\
152 \\
\end{array}$ & $\begin{array}{l}28.5 \\
35.4 \\
36.1 \\
\end{array}$ \\
\hline Gender & $\begin{array}{l}\text { Female } \\
\text { Male }\end{array}$ & $\begin{array}{l}254 \\
167\end{array}$ & $\begin{array}{l}60.3 \\
39.7\end{array}$ \\
\hline Educational level & $\begin{array}{l}\text { High school } \\
\text { Associate } \\
\text { Bachelor } \\
\text { Graduate school }\end{array}$ & $\begin{array}{l}45 \\
46 \\
294 \\
36\end{array}$ & $\begin{array}{l}10.7 \\
10.9 \\
69.8 \\
8.6\end{array}$ \\
\hline Marital status & $\begin{array}{l}\text { Married } \\
\text { Single }\end{array}$ & $\begin{array}{l}161 \\
260 \\
\end{array}$ & $\begin{array}{l}38.2 \\
61.8 \\
\end{array}$ \\
\hline Income & $\begin{array}{l}\text { Less income than expenses } \\
\text { Equal income and expenses } \\
\text { More income than expenses }\end{array}$ & $\begin{array}{l}92 \\
212 \\
117\end{array}$ & $\begin{array}{l}21.8 \\
50.4 \\
27.8\end{array}$ \\
\hline Work experience & $\begin{array}{l}0-4 \text { years } \\
5-9 \text { years } \\
10 \text { years and above }\end{array}$ & $\begin{array}{l}219 \\
117 \\
85\end{array}$ & $\begin{array}{l}52.0 \\
27.8 \\
20.2\end{array}$ \\
\hline Living with the family & $\begin{array}{l}\text { Yes } \\
\text { No }\end{array}$ & $\begin{array}{l}234 \\
187\end{array}$ & $\begin{array}{l}55.6 \\
44.4\end{array}$ \\
\hline Chronic illness & $\begin{array}{l}\text { Yes } \\
\text { No }\end{array}$ & $\begin{array}{l}55 \\
366\end{array}$ & $\begin{array}{l}13.1 \\
86.9\end{array}$ \\
\hline $\begin{array}{l}\text { Working status in coronavirus } \\
\text { units }\end{array}$ & $\begin{array}{l}\text { Yes } \\
\text { No }\end{array}$ & $\begin{array}{l}275 \\
146\end{array}$ & $\begin{array}{l}65.3 \\
34.7\end{array}$ \\
\hline $\begin{array}{l}\text { Having enough information } \\
\text { about coronavirus }\end{array}$ & $\begin{array}{l}\text { Yes } \\
\text { No }\end{array}$ & $\begin{array}{l}341 \\
80\end{array}$ & $\begin{array}{l}81.0 \\
19.0\end{array}$ \\
\hline $\begin{array}{l}\text { Believing that the coronavirus } \\
\text { will end soon }\end{array}$ & $\begin{array}{l}\text { Yes } \\
\text { No }\end{array}$ & $\begin{array}{l}71 \\
350\end{array}$ & $\begin{array}{l}16.9 \\
83.1\end{array}$ \\
\hline $\begin{array}{l}\text { Believing that the coronavirus } \\
\text { is a virus produced in a } \\
\text { laboratory environment }\end{array}$ & $\begin{array}{l}\text { Yes } \\
\text { No }\end{array}$ & $\begin{array}{l}260 \\
161\end{array}$ & $\begin{array}{l}61.8 \\
38.2\end{array}$ \\
\hline $\begin{array}{l}\text { Has anyone caught coronavirus } \\
\text { from your immediate } \\
\text { environment? }\end{array}$ & $\begin{array}{l}\text { Yes } \\
\text { No }\end{array}$ & $\begin{array}{l}137 \\
284\end{array}$ & $\begin{array}{l}32.5 \\
67.5\end{array}$ \\
\hline
\end{tabular}

Table 2. Distribution of nurses' lowest and highest points and average scores from CP19-S

\begin{tabular}{lllc}
\hline Scale-Sub Dimensions & Lowest & Highest & Average Score \\
\hline Psychological & 6.00 & 30.00 & $19.14 \pm 4.91$ \\
Somatic & 5.00 & 25.00 & $10.56 \pm 3.84$ \\
Social & 5.00 & 25.00 & $14.36 \pm 4.13$ \\
Economic & 4.00 & 20.00 & $9.01 \pm 2.85$ \\
Total Score & 21.00 & 100.00 & $53.09 \pm 13.62$ \\
\hline
\end{tabular}


Table 3. Comparison of CP19-S score average according to nurses' introductory characteristics

\begin{tabular}{|c|c|c|c|c|c|c|}
\hline \multirow{5}{*}{ Gender } & \multicolumn{2}{|c|}{ Psychological } & \multirow{2}{*}{$\begin{array}{l}\text { Somatic } \\
\bar{X} \pm S S\end{array}$} & \multirow{2}{*}{$\begin{array}{l}\text { Social } \\
\bar{X} \pm S S\end{array}$} & \multirow{2}{*}{$\begin{array}{l}\text { Economic } \\
\bar{X} \pm S S\end{array}$} & \multirow{2}{*}{$\begin{array}{l}\text { Total Score } \\
\bar{X} \pm S S\end{array}$} \\
\hline & \multicolumn{2}{|l|}{$\bar{X} \pm S S$} & & & & \\
\hline & Male & $17.68 \pm 4.94$ & $10.05 \pm 3.80$ & $13.92 \pm 4.31$ & $8.97 \pm 2.95$ & $50.64 \pm 13.87$ \\
\hline & Female & $20.10 \pm 4.65$ & $10.90 \pm 3.84$ & $14.65 \pm 3.99$ & $9.03 \pm 2.78$ & $54.70 \pm 13.23$ \\
\hline & $\begin{array}{l}\text { Test and p } \\
\text { value }\end{array}$ & $\mathrm{t}=-5.07, \mathbf{p}=\mathbf{0 . 0 0}$ & $\mathrm{t}=-2.20, \mathbf{p}=\mathbf{0 . 0 2}$ & $\mathrm{t}=-1.77, \mathbf{p}=\mathbf{0 . 0 7}$ & $\mathrm{t}=0.24, \mathrm{p}=0.80$ & $\mathrm{t}=-3.01, \mathrm{p}=. \mathbf{0 0 3}$ \\
\hline \multirow[t]{5}{*}{ Age } & $18-24$ & $19.83 \pm 4.54$ & $10.73 \pm 3.91$ & $14.30 \pm 4.14$ & $9.19 \pm 2.99$ & $54.05 \pm 13.45$ \\
\hline & $25-29$ & $18.52 \pm 4.79$ & $10.19 \pm 3.54$ & $14.16 \pm 4.03$ & $8.96 \pm 2.98$ & $51.85 \pm 13.21$ \\
\hline & 30 and above & $19.40 \pm 5.34$ & $10.96 \pm 4.19$ & $14.74 \pm 4.27$ & $8.89 \pm 2.47$ & $54.01 \pm 14.34$ \\
\hline & & $\mathrm{F}=2.83, \mathrm{p}=.060$ & $\mathrm{~F}=1.59, \mathrm{p}=0.204$ & $\mathrm{~F}=.738$ & $\mathrm{~F}=.353, \mathrm{p}=.703$ & $\mathrm{~F}=1.33, \mathrm{p}=.265$ \\
\hline & $\begin{array}{l}\text { Test and } p \\
\text { value }\end{array}$ & & & $\mathrm{p}=0.479$ & & \\
\hline \multirow{6}{*}{$\begin{array}{l}\text { Educational } \\
\text { level }\end{array}$} & High school & $19.13 \pm 4.99$ & $10.48 \pm 3.84$ & $12.97 \pm 4.00$ & $8.33 \pm 2.79$ & $50.93 \pm 13.79$ \\
\hline & Associate & $20.13 \pm 5.57$ & $11.84 \pm 5.24$ & $14.95 \pm 4.89$ & $9.15 \pm 2.89$ & $56.08 \pm 17.34$ \\
\hline & Bachelor & $19.13 \pm 6.92$ & $10.45 \pm 3.58$ & $14.59 \pm 3.98$ & $9.10 \pm 2.84$ & $53.29 \pm 12.91$ \\
\hline & Graduate & $19.13 \pm 4.75$ & $9.91 \pm 3.68$ & $13.47 \pm 4.11$ & $8.91 \pm 2.94$ & $50.27 \pm 13.41$ \\
\hline & school & $\mathrm{F}=1.30, \mathrm{p}=0.27$ & $\mathrm{~F}=2.14, \mathbf{p}=\mathbf{0 . 0 9}$ & $\mathrm{F}=2.91, \mathbf{p}=\mathbf{0 . 0 3}$ & $\mathrm{F}=1.00, \mathrm{p}=0.39$ & $\mathrm{~F}=1.66, \mathrm{p}=0.17$ \\
\hline & $\begin{array}{l}\text { Test and } p \\
\text { value }\end{array}$ & & & & & \\
\hline \multirow{3}{*}{$\begin{array}{l}\text { Marital } \\
\text { status }\end{array}$} & Married & $19.13 \pm 5.12$ & $10.73 \pm 4.10$ & $14.77 \pm 4.24$ & $39.87 \pm 8.03$ & $53.65 \pm 14.03$ \\
\hline & Single & $19.15 \pm 4.78$ & $10.46 \pm 3.68$ & $14.11 \pm 4.05$ & $41.31 \pm 7.94$ & $52.74 \pm 13.37$ \\
\hline & $\begin{array}{l}\text { Test and } p \\
\text { value }\end{array}$ & $\mathrm{t}=0.47, \mathrm{p}=0.96$ & $p=0.48$ & $\mathrm{t}=1.57, \mathrm{p}=0.11$ & $\mathrm{t}=1.55, \mathrm{p}=0.12$ & $\mathrm{t}=0.66, \mathrm{p}=0.50$ \\
\hline \multirow{4}{*}{$\begin{array}{l}\text { Income vs } \\
\text { expenses }\end{array}$} & Less income & $20.20 \pm 5.82$ & $11.66 \pm 4.97$ & $14.54 \pm 5.27$ & $9.55 \pm 3.37$ & $55.96 \pm 17.68$ \\
\hline & Equal & $19.48 \pm 4.23$ & $10.79 \pm 3.53$ & $14.66 \pm 3.52$ & $9.00 \pm 2.65$ & $53.94 \pm 11.59$ \\
\hline & More income & $17.69 \pm 4.98$ & $9.29 \pm 2.94$ & $13.70 \pm 4.09$ & $8.60 \pm 2.69$ & $49.29 \pm 12.63$ \\
\hline & $\begin{array}{l}\text { Test and } p \\
\text { value }\end{array}$ & $\mathrm{F}=8.03, \mathbf{p}=\mathbf{0 . 0 0}$ & $\mathrm{F}=11.05, \mathbf{p}=\mathbf{0 . 0 0}$ & $\mathrm{F}=2.14, \mathbf{p}=\mathbf{0 . 0 0}$ & $\mathrm{F}=2.87, \mathbf{p}=\mathbf{0 . 0 0}$ & $\mathrm{F}=7.22, \mathbf{p}=\mathbf{0 . 0 0}$ \\
\hline \multirow{3}{*}{$\begin{array}{l}\text { Working } \\
\text { status in } \\
\text { coronavirus } \\
\text { units }\end{array}$} & Yes & $19.20 \pm 5.00$ & $10.90 \pm 3.97$ & $14.27 \pm 4.21$ & $9.04 \pm 2.85$ & $53.42 \pm 14.02$ \\
\hline & No & $19.02 \pm 4.74$ & $9.93 \pm 3.51$ & $14.54 \pm 3.98$ & $8.95 \pm 2.84$ & $52.47 \pm 12.86$ \\
\hline & $\begin{array}{l}\text { Test and } p \\
\text { value }\end{array}$ & $\mathrm{t}=0.35, \mathrm{p}=0.72$ & $\mathrm{t}=2.46, \mathbf{p}=\mathbf{0 . 0 1}$ & $\mathrm{t}=0.65, \mathrm{p}=0.516$ & $\mathrm{t}=0.278, \mathrm{p}=0.781$ & $\mathrm{t}=0.68, \mathrm{p}=0.49$ \\
\hline \multirow{3}{*}{$\begin{array}{l}\text { Believing } \\
\text { that the } \\
\text { coronavirus } \\
\text { will end soon }\end{array}$} & Yes & $17.35 \pm 4.05$ & $9.74 \pm 2.72$ & $12.88 \pm 3.35$ & $8.73 \pm 2.33$ & $48.71 \pm 10.34$ \\
\hline & No & $19.50 \pm 4.99$ & $10.73 \pm 4.01$ & $14.66 \pm 4.21$ & $9.06 \pm 2.94$ & $53.98 \pm 14.04$ \\
\hline & $\begin{array}{l}\text { Test and p } \\
\text { value }\end{array}$ & $\mathrm{t}=3.46, \mathbf{p}=\mathbf{0 . 0 0}$ & $\mathrm{t}=1.97, \mathbf{p}=\mathbf{0 . 0 1}$ & $\mathrm{t}=3.80, \mathbf{p}=\mathbf{0 . 0 0}$ & $\mathrm{t}=1.05, \mathrm{p}=0.29$ & $\mathrm{t}=2.99, \mathbf{p}=\mathbf{0 . 0 0}$ \\
\hline
\end{tabular}

\section{Discussion}

This study was conducted to examine the coronavirus fear levels of nurses and the variables affecting them during the COVID-19 outbreak.

The risk of being diagnosed with COVID19 significantly affects society (Ueda et al., 2020). The nurses working actively in the field are very disturbed by the fear of infection, death and the thought that their loved ones can be infected with coronavirus (Kang et al., 2020; Chua, 2004). When faced with a large-scale public health event such as COVID-19, the physical and psychological pressure on nurses should not be overlooked (Wu et al., 2009). In some studies in the literature, it is emphasized that individuals' health and well-being are affected in times of contagious epidemic crisis (Duncan et al., 2009 ; Pappas et al., 2009).

During the COVID-19 outbreak in China, it is stated that the main concerns of nurses are an increase in fear levels due to taking the virus to their homes and families (Chen et al., 2020). In this study, while nurses' fear of COVID-19 was found to be moderate, women's coronavirus fear levels were higher than men. Being a nurse during the pandemic process carries a high risk in terms of fear, anxiety and other mental problems (Lai et al., 2020). In the study conducted by Gao et al., it is stated that women generally have higher levels of fear than men. This is thought to be related to gender characteristics. Women attach more importance to their inner experiences and their self-perceptions 
and emotions are more fragile and sensitive than men. In addition, women are more vulnerable to depression, fear, anxiety, and loneliness (Gao et al., 2003; Shih et al., 2007). The result of this study is similar to the previous study results. The findings of the study revealed there was a statistically significant difference between educational status and fear of coronavirus. It is thought that this difference is due to the nurses' evaluation of the fears about their bodies due to the insufficient knowledge of the nurses about their bodies. A significant relationship was found between the nurses' economic status and COVID-19 fear levels. In our country and in the international literature, it is stated that variables such as gender, education and economy affect the level of fear of individuals (Çelik and Edipoğlu, 2018; Koivula et al., 2020; Ruhaiyem et al., 2016). In this study, it can be said that nurses' having a good economic income reduces the fear of coronavirus that may occur in nurses. The fear level of the nurses whose income is more than the expenses was found to be lower. It is thought that having a good income gives the nurses confidence, better living standards, and the thought that they will not have any problems in getting all kinds of health services.

In this study, the somatic fear levels of the nurses working in the coronavirus units were found to be higher than the other units. The fact that COVID-19 can be transmitted from person to person can increase the fear levels of nurses who care for patients ( $\mathrm{Li}$ et al., 2020; Rothe et al.,2020). In the study conducted by Kang et al., it is stated that the fear levels of nurses who care for COVID-19 patients have increased (Kang et al., 2020). In the study conducted by Lai et al., it was stated that half of the nurses caring for COVID-19 infected patients are experiencing mental problems such as depression and anxiety (Lai et al., 2020). It is stated that nurses struggling at the forefront are in close contact with these patients, especially when they are caring. Contamination, high risk of infection and burnout are associated with fear and anxiety (Kang et al., 2020; Bao et al., 2020). Nurses make up the largest part of the healthcare workforce in epidemics and take on most of the workload in combating infectious diseases (Said et al., 2020; Usher et al., 2009). It is stated that the field nurses who cared for patients during the SARS epidemic have had a lot of physical and mental difficulties while continuing to provide qualified nursing care for patients (Shih et al., 2007; Chan et al., 2003; Mok et al., 2005; Tzeng, 2003). The result of the research is similar to the results of the studies in the literature. The reasons for the higher somatic fear level of nurses working in COVID-19 units compared to nurses in other units are thought to be due to nurses' direct contact with patients, fear of getting sick, the service environment being more stressful and tense than other units, sleepless and intense working pace. In this study, a significant difference was found between nurses' belief that COVID-19 will end in a short time and coronavirus fear levels. In this study, the fear levels of nurses who do not believe that COVID-19 will end in a short time were found to be higher. The psychological response of healthcare professionals to the infectious disease epidemic seems to be quite difficult. Among these difficulties are feelings of vulnerability or loss of control, selfhealth, spread of the virus, family health, changes in the workplace, and concerns about isolation (Wong et al., 2005; Chan, 2004). It is thought that nurses' low belief in the end of the epidemic is due to an uncertainty about the future of the disease in nurses, the lack of a clear treatment solution for the coronavirus, the society's failure to comply with effective prevention rules for the epidemic, and ambiguous statements made by official institutions. It seems that epidemiological data on the mental health of nurses caring for COVID-19 patients and related factors are still limited.

\section{Conclusion}

The results obtained from the study are as follows:

The nurses generally had moderate levels of COVID-19 fear,

The female nurses' fear of COVID-19 was higher than the male nurses,

The nurses with good income level had lower COVID-19 fear levels,

It has been found that the nurses working in COVID-19 units had higher COVID-19 fears.

In line with these results, it may be suggested to include the issue of "coping with fear in outbreaks" more in in-service training programs and improve the income status of nurses. In addition, it is thought that conducting qualitative studies on the fear of COVID-19 will contribute to the solution of the problem.

\section{Limitation}

Failure to reach nurses working in other provinces in Turkey's Eastern Anatolia is the limitation of this study. 


\section{Acknowledgements}

The authors wish to thank and acknowledge the participants for sharing their experiences with us.

Ethics Committee Approval: Approval was obtained from Muş Alparslan Unıversity Ethics Committee for the research(date;04.06.2020, number;10879717-050.01.04).

Hakem/Peer-review: External referee evaluation.

Yazar Katkısı/Author Contributions: Author Contribution:MD; Idea/concept:MD; Design:OFD; Consulting:OFD; Data Collection and/or Data Processing:OFD,MD,HK; Analysis and/or Interpretation:MD,OFD; Source search; OFD,H; Writing of the article:FD,HK; Critical review:MD.

Conflict of interest: The authors declare no conflict of interest in this study.

Financial Disclosure: This research did not receive any specific grant from funding agencies in the public, commercial, or not-for-profit sectors.

\section{What did the study add to the literature?}

- As a result of this study, it was determined that the COVID-19 fear levels of nurses working actively in healthcare institutions were at a moderate level.

- In addition, it was determined that there was a significant difference between nurses' COVID-19 fear levels and their gender, education status, income status, their employment status in risky units, and their belief that COVID-19 would end soon.

\section{Kaynaklar}

Akça Ay F. (2010). Professional basic concepts. In: Akça Ay $\mathrm{F}$, editor. Basic nursing concepts, principles, practices. İstanbul Medikal Yayınc1lk, pp;47-50.

Arpaci I, Karataş K, Baloğlu M. (2020). The development and initial tests for the psychometric properties of the COVID-19 Phobia Scale (C19P-S). Personality and Individual Differences, 110108 https://doi.org/10.1016/j.paid.2020.110108

Bao Y, Sun Y, Meng S, Shi J, Lu L. (2020). 2019 -nCOV Epidemic: address mental health care to empower society. The Lancet, 1, e 37-8. https://doi.org/ 10.1016/S0140-6736(20)30309-3

Baksi A, Sürücü HA, Kurt G. (2020). Hemşirelerin Bireysel Yenilikçilik Davranışları ve Bu Davranışları Etkileyen Faktörlerin İncelenmesi. ACU Sağlık Bilimleri Dergisi, 11(2), 310-315. https://doi.org/10.31067/0.2020.269310

Çelik F, Edipoğlu IS. (2018). Evaluation of preoperative anxiety and fear of anesthesia using APAIS score. European Journal of Medical Research, 23(41).

Chan S. (2003).Nurses fighting against severe acute respiratory syndrome (SARS) in Hong Kong. Journal of Nursing Scholarship, 35(3), 209.

https://doi:10.1111/j.1547-5069.2003.00209.x
Chan-Yeung M. (2004). Severe acute respiratory syndrome (SARS) and healthcare workers. International Journal of Occupational and Environmental Health, 10(4), 421-427. https://doi:10.1179/oeh.2004.10.4.421

Chen Q, Liang M, Li Y, Guo J, Fei D, Wang L et al. (2020). Mental health care for medical staff in China during the COVID-19 outbreak. Lancet Psychiatry, 7(4):e15-e16. https://doi.org/10.1016/S2215-0366(20)30078-X

Chua SE, Cheung V, Cheung C, Alonan GM, Wong JWS, Chueng EPT et al. (2004). Psychological effects of the SARS outbreak in Hong Kong on high-risk health care workers. The Canadian Journal of Psychiatry, 49(6):391-393. doi:10.1177/070674370404900609

Cohen L, Manion L, Morrison K. (2013). Research methods in education. Routledge, pp;100-104.

Çankaya, M, Eriş, H . (2020). Hemşire ve ebelerin duygusal zeka düzeylerinin tespitine yönelik bir çalışma. Elektronik Sosyal Bilimler Dergisi,19(74), 656-664. https://doi. org/10.17755/esosder.567278

Duncan LA, Schaller M, Park JH. (2009). Perceived vulnerability to disease: Development and validation of a 15-item self-report instrument. Personality and Individual Differences, 47(6), 541-546. https://doi. org/10.1016/j.paid.2009.05.001.

Durmuş M , Gerçek A Çiftci N . (2018). Hemşirelerin yaşam kaliteleri ile tükenmişlik düzeylerinin değerlendirilmesine yönelik bir araştırma. Anemon Muş Alparslan Üniversitesi Sosyal Bilimler Dergisi,6 (2), 279-286. https://doi. org/ 10.18506/anemon.325977

Gao WB, Chen ZY, Wang YN. (2003). Analysis on the influence and change trend of public mentality during sars epidemic. Chinese Mental Health Journal, 17(9): 594-596.

Guan WJ, Ni Z, Hu Y, Liang C, Ou J, He L et al. (2020). Clinical characteristics of coronavirus disease 2019 in China. New England Journal of Medicine, 382(13), 1199-1207. https://doi.org/10.1056/NEJMoa2001316

Huang C, Wang Y, Li X, Ren L, Zhao J, Hu Y et al. (2020). Clinical features of patients infected with 2019 novel coronavirus in Wuhan. China. Lancet, $395,497-506$. https://doi.org/10.1016/S0140-6736(20)30183-5

Kang L, Li Y, Hu S, Chen M, Yang BX, Wang Y et al. (2020). The mental health of medical workers in Wuhan. China dealing with the 2019 novel coronavirus. Lancet Psychiatry, 7(3), 14. https://doi.org/10.1016/S2215-0366(20)30047-X

Khamisa N, Peltzer K, Oldenburg B. (2013). Burnout in relation to specific contributing factors and health outcomes among nurses: A systematic review. International Journal of Environmental Research and Public Health, 10(6), 221440. https://doi.org/10.3390/ijerph10062214

Kizılırmak M, Demir S. (2016). Investigation of depression and quality of life in hospital nurses.(in 
Turkish). TAF Preventive Medicine Bulletin, 15(2), 132-40.

Koivula M, Tarkka MT, Tarkka M, Laippala P, Paunonen-Ilmonen M. (2002). Fear and anxiety in patients at different time-points in the coronary artery bypass process. International Journal of Nursing Studies, 39, 811-822.https://doi.org/ 10.1016/s00207489(02)00022-6

Korkmazer, F, Pirol, M, Güneysu, E. (2020). Hemşirelerin hastane etik iklim algılarının performansları üzerine etkisi. Anemon Muş Alparslan Üniversitesi Sosyal Bilimler Dergisi , 8 (1) , 163-170. https://doi. org/ 10.18506/anemon.523438

Köse S, Sis Çelik A . (2020). Hemşirelerin hemşirelik tanılarını algılama durumlarının ve etkileyen faktörlerin belirlenmesi. Ordu Üniversitesi Hemşirelik Çalışmaları Dergisi, 3 (3), 244-253. https://doi.org/ 10.38108/ouhcd.785110

Lai J, Ma S, Wang Y, Cai Z, Hu J, Wei N et al. (2020). Factors associated with mental health outcomes among health care workers exposed to coronavirus disease. JAMA Netw Open, 3, e203976. https://doi.org/10.1001/jamanetworkopen.2020.3976

Li L, Cheng S, Gu J. (2003). SARS infection among health care workers in Beijing, China. JAMA, (20): 2662-2663. https://doi:10.1001/jama.290.20.2662.

Li Q, Guan X, Wu P, Wang X, Zhou L, Tong Y et al. (2020). Early transmission dynamics in Wuhan, China, of novel coronavirus-infected pneumonia [published online January 29, 2020]. New England Journal of Medicine, https://doi:10.1056/NEJMoa2001316

Lin CY. (2020). Social reaction toward the 2019 novel coronavirus (COVID-19). Social Health and Behavior, 3(1), 1-2. https://doi.org/10.4103/SHB.SHB_11_20.

Mok E, Chung BP, Chung JW, Wong TK. (2005). An exploratory study of nurses suffering from severe acute respiratory syndrome (SARS). International Journal of Nursing Practice, 11(4), 150-160. https://doi:10.1111/j.1440-172X.2005.00520.x

Muşlu C, Baltacı D, Kutanis R, Kara İH. (2012). Nurses working in primary care and hospitals anxiety, depression, and quality of life(in Turkish). Konuralp Medical Journal, 4(1), 17-23.

Öz F. (2015). Basic concepts in the field of health. 2nd Edition. Ankara. Mattek publishing, pp.38-42.

Pappas G, Kiriaze IJ, Giannakis P, Falagas ME. (2009). Psychosocial consequences of infectious diseases. Clinical Microbiology and Infection, 15(8), 743-747. https://doi.org/10.1111/j.14690691.2009.02947.x.

Paules CI, Marston HD, Fauci AS. (2020). Coronavirus infections-more than just the common cold. JAMA, https://doi.org/10.1001/jama.2020.0757

Rothe C, Schunk M, Sothmann P, Bretzel G, Froeschl G, Wallrauch C, et al. (2020). Transmission of 2019. $\mathrm{nCoV}$ infection from an asymptomatic contact in
Germany [published online January 30, 2020]. New England Journal of Medicine, https://doi:10.1056/NEJMc2001468

Ruhaiyem ME, Alshehri AA, Saade M, Shoabi TA, Zahoor H, Tawfeeq NA. (2016). Fear of going under general anesthesia: A cross-sectional study. Saudi Journal of Anaesthesia, 10(3), 317-321. https://doi.org/ 10.4103/1658-354X.179094

Said NB, Chiang VCL. (2020). The knowledge, skill competencies, and psychological preparedness of nurses for disaster: a sytematic review. International Emergency Nursing, 48: 100806. https://doi.org/ 10.1016/j.ienj.2019.100806

Shih FJ, Gau ML, Kao CC, Yang CY, Lin YS, Liao YC et al. (2007). Dying and caring on the edge: Taiwan's surviving nurses' reflections on taking care of patients with severe acute respiratory syndrome. Applied Nursing Research, 20(4),171-180. https://doi:10.1016/j.apnr.2006.08.007

Tzeng, H, Ketefian, S (2003). Demand for nursing competencies: an exploratory study in Taiwan's hospital system. Journal of Clinical Nursing, 12 (4), 509-518.

Ueda M, Martins R, Hendrie PC, Donnell T, Crews JR, Wong TL et al. (2020). Managing cancer care during the COVID-19 pandemic: agility and collaboration toward a common goal. Journal of National Comprehensive Cancer Network, https://doi.org/10.6004/jncen.2020.7560.

Usher K, Gardner A, Buttner P, Woolley T. (2009). The H1N1 influenza 09 and its potential impact on the Australian nursing workforce. Collegian, 16(4), 16970. https://doi.org/10.1016/j.colegn.2009.10.001

Wong TW, Yau JK, Chan CLW, Kwong RSY, Ho SMY, Lau CC et al.(2005). The psychological impact of severe acute respiratory syndrome outbreak on healthcare workers in emergency departments and how they cope. European Journal of Emergency Medicine, 12(1), 13-18. https:// doi:10. 1097/00063110-200502000-00005

Wu P, Fang Y, Guan Z, Fan B, Kong J, Yao Z et al. (2009). The psychological impact of the SARS epidemic on hospital employees in China: exposure, risk perception, and altruistic acceptance of risk. Canadanian Journal of Psychiatry, 54:302-311. https://doi.org/10.1177\%2F070674370905400504

Xu Z, Shi L, Wang Y, Zhang Y, Huang L, Zhang C et al. (2020). Pathological findings of COVID-19 associated with acute respiratory distress syndrome. Lancet Respiratory Medicine, 8:420-422. https://doi.org/10.1016/S2213-2600 (20)30076-X 